A N N A L E S

UNIVERSITATIS M A R I A E C URIE-SKŁODOW S K A

LUBLIN - POLONIA

VOL. XXXIII, 3

SECTIO J

2020

Maria Curie-Skłodowska University in Lublin. Faculty of Education and Psychology

\author{
CEZARY W. DOMAŃSKI \\ ORCID: 0000-0003-2408-0706 \\ cezary.domanski@poczta.umcs.lublin.pl
}

\title{
Emotions and Feelings in Psychology Textbooks Published in Poland until 1914. Description, Classifications, Interpretations
}

Emocje i uczucia w podręcznikach psychologii wydanych w Polsce do 1914 roku.

Opis, klasyfikacje, interpretacje

How to Quote this Paper: Domański, C.W. (2020). Emotions and Feelings in Psychology Textbooks Published in Poland until 1914. Description, Classifications, Interpretations. Annales Universitatis Mariae Curie-Skłodowska. Sectio J, Paedagogia-Psychologia, 33(3).

\begin{abstract}
Textbooks form one of the most important sources of knowledge on issues that construct the area of research of the respective scientific discipline. The knowledge contained in them relates to the current state of cognition, reflects scientific terminology, explains how various phenomena are defined, and their mechanisms understood and what meaning are they given in the system of the respective science. Therefore, their role in the school and academic teaching is a fundamental one. Furthermore, they also inspire research directions and topics, at least to some extent. The article outlines the place of emotions and feelings in the most significant psychology textbooks published in Polish from 1863 to 1914. These include both the works of Polish psychologists as well as works translated from foreign languages. The author demonstrates, how the knowledge of feelings and emotions, their classification, and also the basic views concerning their origins and links to other phenomena of consciousness were all presented. We may consider this state of knowledge the starting point for all further development of psychology of emotions in Poland.
\end{abstract}

Keywords: emotions; feelings; psychological textbooks; history of psychology in Poland

\section{INTRODUCTION}

Polish subject literature only has a few works devoted to the historic development of various subdisciplines of psychology. History of psychology of emotions remains an uncharted area here. It seems that we should start filling this gap 
by analyzing the most important psychology textbooks published in Polish. They form an important source of knowledge about how feelings and emotions were perceived in science at the turn of the century, as well as how they were described, defined and classified.

Already in 1901, Adam Mahrburg in his Poradnik dla samouków drew attention to the importance of textbooks from the point of view of the development of the respective discipline and their significance in the education process. Although only a handful of psychology textbooks appeared at the turn of the $19^{\text {th }}$ and $20^{\text {th }}$ century, the ones that reached publication form an abundant source of knowledge concerning the place of both emotions and feelings in psychological systems, and in our native language for description of psychological phenomena. Therefore, it is worth taking a closer look at this issue, while bearing in mind that the period described in the present article was also the period of transition from the rational, philosophical psychology, to the psychology that was already emancipated as an independent discipline of science. ${ }^{1}$

\section{EMOTIONS IN THE TEXTBOOKS OF POLISH AUTHORS}

One of the first university textbooks partly devoted to psychology was the collection of lectures by Henryk Struve, a professor at the Main School in Warsaw. What we are talking about is Logika poprzedzona wstepem psychologicznym, which was published in 1863, using letter copying presses. The majority of lectures was devoted to cognitive processes (thinking, intellect, reason, comprehension) as their relationship with logic seemed to be the most obvious for their author. Struve distinguished three powers of soul: thinking, feeling and will. These three basic manifestations of activity of soul translate into psychological principles, which are: mentality, emotionality and will. Struve also uses the terms przyjemność ("pleasure") and nieprzyjemność ("unpleasantness") to describe the way "in which all sensual impressions are revealed to us" (Struve, 1863, p. 59). The act of feeling that transforms sensations into certain emotional forms of the soul is czułość ("affection”). When writing about feeling, he usually refers to aesthetic feelings. From the comments scattered around his lectures, we can learn that "the whole emotional life (...) of man lies (...) completely beyond all thinking, exerting (...) independent influence on this thinking" (p. 147). The issue of emotions in Struve's lectures was treated marginally and reflects the centuries-old attitude of philosophical psychologists to this issue. We should emphasize here, that the term emocja ("emotion") is nowhere to be found in his entire book.

1 The source basis for this article was the Biographical Dictionary of Polish Psychologists containing a psychological bibliography until 1939. This source was compiled by the author. Research methodology described i.a. Howell and Prevenier (2001). 
The handbook of Mikołaj Lipiński, who is considered to be the author of one of the first Polish scientific psychology projects (Rzepa, Dobroczyński, 2019), was published less than five years later. Although he could not decide whether to call the science of soul the "psychological anthropology" or "empirical psychology", his version of psychology managed to capture a full spectrum of various psychological issues in a fairly comprehensive manner. The title "psychological anthropology" was, for its author, "an ability aimed at systematically learning about mental appearances and mental varieties of man, in short, a systematic discovery of mental life" (Lipiński, 1867, p. 14). The term "emotion" also fails to appear in this textbook, nevertheless, experiences such as uczucie ("feeling") and pożądanie ("desire") are extensively described. They appear in different contexts. The author wrote about their origins and relationships with other mental processes. He also attempted to classify them. Thus, feelings can either stem from the organic condition of the body, or be the result of intelligent sensuality. The latter form the class of higher feelings, which includes all moral feelings, feelings related to the idea of truth, and aesthetic feelings. The comparison of one's own (or someone else's) thought and behaviour with the idea of good forms the origin of moral feelings. Therefore, such conditions as "peace of soul", "internal satisfaction", "self-respect" and "respect for others" also belong here. Lipiński included religious feelings to the feelings related to the idea of truth, while the detailed characteristics of aesthetic feelings was, according to him, the task of aesthetics, and not psychology.

We find a further step in the direction towards the systematization and development of terminology in the psychology textbook elaborated by Józef Zagórzański (1869), a high school teacher, based on the work of one of the German authors. It was, as the author states in his introductory note, a natural approach to psychology. The whole second section of the book was devoted to the systematic approach to emotional processes, still without the use of the term "emotions", which were generally referred to as uczucia ("feelings"). Zagórzański divided feelings into sensual and non-sensual ones, and the latter further into objective and subjective ones. According to him, the objective feelings included aesthetic, ethical, religious and intellectual ones. Subjective feelings are the feelings of excess or lack of strength, feelings of mental fullness or boredom, and mixed feelings. Zagórzański also wrote about the reproduction of feelings, sympathies and antipathies, sympathetic feelings, affects and their divisions. In the third chapter of his handbook he also covers issues from the field of psychology of emotions. They concerned the condition referred to as dązenie ("pursuit"), i.e. the desire for a pleasant feeling, and also experiences related to sensual desire (drive, lust, inclination, addiction, passion) and non-sensual desire (want and wish). What is interesting is also the definition of feeling by Zagórzański: "feeling is a mental condition, in which something happens to us (...) in which the dominance of the excitability of the soul 
over its independence manifests itself, and the soul behaves reluctantly" $(1869, \mathrm{p}$. 93). Zagórzański includes an important note in his textbook, concerning the mixing of psychological conditions of czucie ("sensing") and uczucie ("feeling") in contemporary life. While sensation is the primary, objective condition of the soul (caused by external objects or bodily processes), the feeling consists in supporting or suppressing imaginations, having a subjective origin. Nevertheless, we should also note that the author classifies these two terms in the same set of concepts.

The textbook by Bazyli Ilnicki (under the initials "B.I.") was published in 1874, and entitled Zarys psychologii empirycznej. This book forms an example of a certain regression of views on psychology of emotions, and more precisely of the logical synthesis of issues that form its subject. Within detailed psychology, Ilnicki distinguished "theoretical powers" (such as perception, senses, imagination, memory, fantasy, reason, speech, etc.) and "practical powers". In the latter area, he contained problems from the field of emotional psychology scattered in such topics as: drive, will, character and affect. However, what is important in this textbook, is that if features the term emocja ("emotion") (as the sole one from all the books analyzed in the present article)! While describing the concept of czucie ("sensing") (i.e. awareness of the physical condition), the author wrote that "sensing consists of two main factors: 1) wrażenie (afekcja), i.e. impression (affection), and 2) wzruszenie (emocja), i.e. agitation (emotion). The first factor can be referred to as an objective one, while the second as subjective (Ilnicki, 1874, p. 71). He also described the features of impressions or emotions, distinguishing the degree of feeling (can be strong or weak) and the tone of feeling (can be pleasant or unpleasant and subject related, the same for all people and relative, subjective). The term "emotion", however, was not used explicitly by Ilnicki; the author treated it as a synonym of two different concepts (sense of feeling, emotion).

The next textbook was written by associate professor at the Jagiellonian University, Teofil Zygmunt Ziemba. His work, entitled Psychologia, had two editions (in 1877 and 1897). In an introductory note, the author states that his psychological considerations are based on physiology. Psychology is the skill of studying and explaining spiritual phenomena. The book includes an extensive chapter on Uczucia ("Feelings"), in which the author discusses the relations of these conditions to thinking and sensing, presents a fairly detailed division of feelings, also including the issue of temperament in the said chapter. In general considerations, Ziemba wrote that "man feels, thinks and desires. In fact, this forms a fine division of our spiritual life" (1877, p. 16). Then he defines feelings as the awareness of everything "which works through the senses from outside or takes place directly in our body or mind, initiating a kind of passive movement of our souls" (ibid., p. 105). Ziemba divided feelings in terms of their content into those arising from the needs of the body, those arising from mental needs, and the feelings of beauty, truth and goodness. The second division of feelings, due to their severity, includes moderate 
and "surged" feelings. He classified feelings such as: joy, anger, fear, sadness and despair separately. He also characterized laughter and crying as manifestations of feelings. The inclusion of temperament in the psychology of feelings was justified by the fact that temperament is an innate emotional disposition. He divides the temperament in a classical manner (i.e. distinguishing sanguine, choleric, melancholic and phlegmatic temperaments). To sum up his textbook, it should be added that Ziemba does not use the term "emotion" anywhere.

In 1895, the book of Rev. Aleksander Pechnik entitled Zarys psychologii dla użytku szkót średnich was published. According to the author, "psychology deals with the study of spiritual phenomena and the laws, to which they are subject" (p. 2). He further wrote that "already in everyday speech there is a clear division of spiritual phenomena into three separate groups, one of which includes imaginations and thoughts, the other pleasant and unpleasant feelings, and the third drives, desires and aspirations" (ibid.). We notice immediately that the author places emotional experiences in the second and third group. This is also how he describes them in his textbook. Pechnik pointed out that it is necessary to distinguish between mental conditions attributed to the "head" and those that originate from the "heart". He also emphasized the fact that there is a mutual interaction between all the elements of consciousness, so that cognition, feeling and will be present in every mental condition. He described the features and types of feelings in detail. According to him, the fact that every feeling was either pleasant or unpleasant was the basic distinguishing feature. Feelings also have their strength. He introduced the concept of relative feelings (astonishment or surprise) appearing due to the result of experience of opposites between the previous and the subsequent mental state. In his division of feelings, Pechnik contrasted those that are caused by condition of the body and changes occurring in it, to those which have their source in frequently purely spiritual ideas and needs, as well as those that result from events that do not directly affect the body and its organs. Among the various types of feelings, Pechnik described self-love, feelings towards others (social feelings), aesthetic feelings, and the intellectual, moral and religious feelings. In turn, he included passions to desires. Pechnik did not use the term "emotions".

Jan Doroziński's handbook entitled Zarys psychologii elementarnej. Podręcznik do użytku szkolnego i prywatnego had two editions: the first in 1909 and the second (revised and supplemented) in 1925. According to his lectures, mental phenomena, also called "facts (manifestations, phenomena) of consciousness" are to form the subject of psychology. Its task is to describe, classify and explain the facts of mental life. Doroziński wrote that all three types of mental phenomena (cognition, feeling and aspiration) are in the closest relationship to each other. Despite their basic similarity, there are also significant differences between them: "feelings are our own, purely subjective, purely internal mental states" (Doroziński, 1909, p. 11). The author dedicated a separate chapter to feel- 
ings. What it discussed, among others, were the characteristics of a feeling, the relations of feelings to cognitive phenomena, and the division of feelings. Subsequent subsections thereof were entitled: "Bodily and Sensual Feelings", "Individual Feelings", "Compassion", "Social Feelings", "Intellectual Feelings", "Moral Feelings", "Religious Feelings", "Aesthetic Feelings", and, in addition, "Affects", i.e. mental affections and dispositions, as well as mood. The most characteristic feature of feelings is their pleasure or unpleasantness. This is the "tone of feeling". Other characteristics of feelings include their strength and duration. The strength of a feeling, which may be weak or strong, depends on the strength of impressions or ideas and the imaginative connections. The duration of the feeling depends on the persistence of the factors causing the feeling. In general, "the tone and strength of feelings depend, very much, on the general state of our consciousness" (Doroziński, 1909, p. 99). Like most of his predecessors, Doroziński did not use the term "emotion" in his textbook.

\section{EMOTIONS AND THE FOREIGN TEXTBOOKS TRANSLATED INTO POLISH}

One of the first translations of psychology textbooks by foreign authors was the book Lectures on Human and Animal Psychology by Wilhelm Wundt (1874). The second volume was devoted almost entirely to uczucia ("feelings") (both the sensual and complex ones), as well as żadze ("desires"). There is no doubt that Wundt's views had some impact on Polish psychology, but from the point of view of the form of this handbook, this was more a collection of unrelated lectures rather than an example of logically structured content. Unfortunately, Wundt's main textbook Grundzüge der physiologischen Psychologie, in which he presented his mature theory of emotions, significant from the point of view of research on these processes, was not translated into Polish. It would be a better form of popularizing the views of the "father of modern psychology" on processes of emotions and feelings.

Several other typical textbooks on psychology were also translated into Polish at the turn of $19^{\text {th }}$ and $20^{\text {th }}$ century. Their authors included Johannes Crüger (1878), John Clark Murray (1887), Harald Høffding (1890), Charles Richet (1890) and Gustav Adolf Lindner (1895). The textbook by Crüger, entitled Grundriss der Psychologie: Für Den Unterricht Und Die Selbstbelehrung bears the Polish title of Zarys psychologii do użtku szkolnego i nauki prywatnej. The author applied the traditional division of mental phenomena into the phenomena of imagining, feeling and desire. As the author himself wrote, "together they constitute the content of science called psychology. Psychology is therefore a science of mental phenomena, or phenomena of the life of our soul" (Crüger, 1873/1878, p. 2). In the chapter devoted to feelings, the textbook has been significantly modified by 
its translator, Zygmunt Sawczyński, who introduced illustrative descriptions of experiences taken from Polish literature (quotes from Mickiewicz, Lenartowicz, Żmichowska, Malczewski, Syrokomla and others). The feeling was defined as a pleasant or unpleasant state of the soul. Two forms of affection: contentment and dissatisfaction are associated therewith. The author stated that there are virtually no mixed feelings, and the belief that they are mixed, results from the rapid succession of opposing feelings. He divided feelings into general and special ones. According to him, the first category included: feelings of work and rest, strength and ineptitude, hope and fear, as well as success and failure. In the latter group, he included sensual, intellectual, aesthetic, moral and religious feelings. In addition, he highlighted emotion of mind (affect). According to him, the phenomena of desires formed a separate category. He divides them into the phenomenon of sensual desire (sensual impulses and inclinations, inclinations), the phenomenon of desire of reason, i.e. want (will), and the phenomenon of intellectual desire associated with character.

In 1887, a translation of the book by Canadian psychologist John Clark Murray, A Handbook of Psychology, was published, under the Polish title Zasady psychologii. Podręcznik. It is worth noting that among the translators was Jan Władysław Dawid, an outstanding pioneer of educational psychology in Poland. As the author stated, "psychology is the name now generally applied to the science which investigates the phenomena of the mind" (Murray 1885/1887, p. 1). We find the discussion of feelings in the detailed part. At the beginning, the translators sorted out the terminology concerning them; they said that this function of mental life has various names: sentiments, emotions, feelings. The expression afekt ("affect") encountered in this context should be limited to a certain class of feelings, while namiętność ("passion") refers to various feelings of extraordinary intensity. The section on how to express feelings is of particular interest, as other textbooks fail to discuss it. Murray divided the signs of feelings into three classes: 1) articulate language expressing feelings and thoughts, 2) actions voluntarily adopted to express feelings, e.g. established uses of courtesy, exclamations and various ways of expressing feelings adopted by individuals or specific communities, 3) other expressive actions that express emotions that are universal for all people (paleness of fear, blush of shame, etc.). He used his own classification of feelings for sensual feelings, feelings originating in association (in relation nature, oneself and others), feelings beginning in comparison, intellectual feelings and practical feelings (those accompanying activities).

Handbook of the Danish psychologist Harald Høffding, Psychologi i Omrids paa Grundlag af Erfaring (Polish title Psychologja w zarysie na podstawie doświadczenia), was translated by Adam Mahrburg from the fourth German edition entitled Psychologie. In Umrissen auf Grundlage der Erfahrung, which was in turn elaborated on the basis of the fifth Danish edition. Høffding treated psy- 
chology as a "theory of sensations, imaginations, feelings and manifestations of will" (1908/1911, p. 3), or the theory of consciousness phenomena. The sixth chapter of his book is devoted to "Psychology of Feelings", containing numerous issues that were not addressed in other textbooks. He wrote about the differences between feelings and sensations (also in a developmental context). He recognized such experiences as: a) disgust, worry, hatred, b) love, joy, sympathy, c) drive, desire, longing, d) hope, fear, e) mixed feelings, as the primary feelings. He developed some of these topics in the sections devoted to egoistic and sympathetic feelings. He also outlined the physiology and biology of feelings and listed the laws concerning the feelings and emotional life. He also characterized the impact of feelings on cognitive processes in detail.

Charles Richet's textbook is originally entitled Essai de psychologie générale. In 1890, it was translated into Polish and published under the title Zarys psychologii ogólnej. What we find in it, is a rather unusual definition of psychology according to which "psychology, as it is commonly adopted, is a science of intelligence, meaning what is going on in ourselves" (Richet 1887/1890, p. 1). There is no separate section on feelings in his handbook. They are mentioned only marginally, as accompanying other processes. Where others wrote about feelings, Richet wrote about "sensations accompanied by emotions". In his textbook, the adjective derived from the word "emotion" appears three times. These are the following expressions: "emotional state", "emotional sensation" and "emotional position".

A separate chapter was also devoted to feelings in Gustav Adolf Lindner's textbook Lehrbuch der empirischen Psychologie, als induktiver Wissenschaft (Polish translation Wyklad psychologii empirycznej). The starting point for establishing their definition are considerations on their origin. On this basis, he decided that "feeling (...) is an experience of support or taming of ideas" (Lindner $1891 / 1895$, p. 116). He also stated that "feelings represent a vague, subjective condition of the soul, so they will never have an unambiguous content" (ibid., p. 117). A characteristic feature of feelings is their "tone" by which they can be divided into the pleasant and unpleasant ones. The strength of feelings depends on their supports and obstacles (i.e. what supports or inhibits them in our consciousness). In turn, the persistence (duration) of feelings depends on the constant keeping of ideas in consciousness. Lindner divided feelings according to the ideas they are related to, into the general (unspecified) and detailed (explicit) ones. According to the second division, feelings may be lower or higher. General feelings are usually lower. In specific feelings, the lower ones are associated with impressions and reproductions, while the higher ones - with imaginations that are managed by reason and mind. General feelings include those that involve work and respite. Detailed lower-level feelings are the sensual feelings (bodily, of taste, sight, etc.). Other feelings in this category are related to discovering something, waiting for 
something and finally getting it, searching and finding, success or failure. Higher feelings depend on the object that triggers them, and therefore on truth, beauty and goodness. Furthermore, Lindner described intellectual, aesthetic (dividing them into elementary and general, and the aesthetic taste), moral and religious feelings, and also the feeling of consciousness (the subject of which is self-awareness) and compassion. He discussed the mutual influence of feelings, describing it as "emotional mood". He also introduced the concept of "affect" or strong mental agitation. He stated that the division of affects corresponds to the division of feelings. They can be "stimulating" (e.g. anger, joy, delight, enthusiasm, dissolution) or "incapacitating" (e.g. fear, amazement, embarrassment, depression, shame, fear, terror, repentance, despair, pettiness). It should be mentioned that Lindner also discusses dążenia (pożadania) (i.e. "aspirations" [desires]) that remain in the relation to similarity to feelings. He includes, e.g. "passion" to the desires. In conducting analogies between different states of consciousness, he states, among others, that "affects arise from feelings, passions from desires" (ibid., p. 172).

\section{CONCLUSIONS}

What results from the above review is that the way of transferring knowledge about various psychological phenomena in textbooks published in Polish lands at the turn of the $19^{\text {th }}$ and $20^{\text {th }}$ century was quite arbitrary and, in terms of terminology and definitions, was different from the aspirations of those of the researchers, who called for the elaboration of a national language of psychology (Potocki, 1897a, 1897b; Radziwiłłowicz, 1911). It could be the result of the fact that textbooks and general works, fulfilling the role of textbooks, were most often written by people, who did not conduct their own psychological research, and instead usually compiled knowledge derived from various studies, most often foreign ones. These were thus high school teachers rather than members of academia. It should be remembered that at that time psychology was not yet a field of independent study, and yet it already appeared as a subject of teaching in secondary schools, and sometimes as a topic of research work conducted by university employees, representing various scientific disciplines. This did not change until the interwar period, when chairs and seminars of psychology were first established.

Based on the content analysis of psychology textbooks published in Polish, we should note that although they devoted significant space to description of emotional phenomena, what was characteristic for them were the arbitrariness and ambiguity of language they applied to that description. The term "emotion" appears in just one textbook, the majority of the remaining ones refer to the emotional conditions using the term "feeling". It is worth mentioning that the word "emotion" was not foreign to Polish in mid-19 ${ }^{\text {th }}$ century, as evidenced by the fact that Michat Amszejewicz's dictionary, entitled Dykcjonarz zawierajacy: wyrazy $i$ wyrażenia 
z obcych języków polskiemu przyswojone (...) contains the following: "Emotion (from French), affection" (1859, p. 119). However, it was used primarily in literary texts (in plural form of "emotions"), and it did not come to scientific language until much later, i.e. in the first half of the $20^{\text {th }}$ century.

In addition to the review, we must add that the first monograph devoted exclusively to the psychology of feelings appeared in Polish at the end of the $19^{\text {th }}$ century. It was a translation of the work of the above-mentioned Harald Høffding Psychology of Feelings and Will (1891). This was followed by works translated from French and written by Théodule Armand Ribot: La psychologie des sentiments (Psychologia uczuć) (1901), Problèmes de psychologie affective (Z zagadnień psychologii uczuć) (1912) and Lalogique des sentiments (Logika uczuć) (1921) (Domański, 2008). The first Polish psychologist to publish a work devoted to the psychology of emotion was Władysław Heinrich. His Psychologia uczuć appeared in 1907. Wacław Radecki was also interested in the issue of emotions. In 1912, he published the book Psychologia wzruszenia i uczuć, which was based on lectures that he had given in the summer semester of that year at the University of Geneva. Unfortunately, in addition to the review of the research, this book also contained unreliable results of the psychoelectrical method he applied to study emotions, which met with rather harsh criticism (Domański, 2018).

The knowledge about emotions and feelings and their place in the general psychology system derived from the Polish textbooks did not differ from what was written on this topic in other languages. It was universal knowledge, adopted as the basis for understanding and classifying feelings both in the works representing the philosophical current and the naturalistic current in contemporary psychology. More psychology textbooks were published in Poland in the interwar period, by Antoni Feliks Mikulski (1925), Rafał Radziwiłłowicz (1926), Władysław Witwicki (1926-1927 and 1929) and Kazimierz Dworak (1933), introducing new content to the psychology of emotions. Nevertheless, the evolution that this subdiscipline underwent from the birth of scientific psychology to the outbreak of World War II deserves a separate study.

\section{REFERENCES}

Amszejewicz, M. (1859). Dykcjonarz zawierajacy: wyrazy i wyrażenia z obcych języków polskiemu przyswojone (...). Warszawa: W drukarni Alexandra Gins.

Crüger, J. (1873/1878). Zarys psychologii do użytku szkolnego i nauki prywatnej. Transl. Z. Sawczyński. Lwów: Nakładem księgarni J.M. Himmelblaua.

Domański, C.W. (2008). Zapomniany inspirator. Théodule Armand Ribot i recepcja jego pogladów psychologicznych w Polsce na przełomie XIX i XX wieku. Lublin: Wydawnictwo UMCS.

Domański, C.W. (2018). Historia psychologii w Europie Środkowej. Badacze, inspiracje i koncepcje. Warszawa: Wydawnictwo Naukowe PWN. 
Doroziński, J. (1909). Zarys psychologii elementarnej. Podręcznik do użytku szkolnego i prywatnego. Kraków: Nakładem autora.

Doroziński, J. (1925). Zarys psychologii elementarnej. Podręcznik do użytku szkolnego i prywatnego. Wydanie drugie. Kraków: Nakładem autora.

Dworak, K. (1933). Zarys psychologii empirycznej. Podręcznik szkolny. Kielce: Nakładem autora.

Høffding H. (1908/1911). Psychologja w zarysie na podstawie doświadczenia. Transl. A. Mahrburg. Warszawa: Nakładem Henryka Lindenfelda.

Howell, M., Prevenier, W. (2001). From Reliable Sources: An Introduction to Historical Methods. Ithaca: Cornell University Press.

Ilnicki, B. [B.I.]. (1874). Zarys psychologii empirycznej. Lwów: Drukarnia Towarzystwa im. Szewczenki.

Lindner, G.A. (1891/1895). Wykład psychologii empirycznej. Transl. L. Kulczyński. Kraków: W.L. Anczyc i Spółka.

Lipiński, M. (1867). Zarys antropologii psychicznej czyli psychologii empirycznej dla użytku dojrzalszej młodzieży polskiej. Lwów: Nakładem autora.

Mahrburg, A. (1901). Psychologja. In: W. Biegańskii in. (red.). Poradnik dla samouków. Część I. Matematyka. Nauki przyrodnicze. Wydanie II (pp. 549-643). Warszawa: Gebethneri Wolff.

Mikulski, A. (1925). Podręcznik psychologji dla użytku studentów medycyny i lekarzy. Wilno: Księgarnia Stowarzyszenia Nauczycielstwa Polskiego.

Murray, C. (1885/1887). Zarys psychologii. Podręcznik. Transl. H. Wernic, J.W. Dawid. Warszawa: Nakładem Księgarni Teodora Paprockiego i S-ki.

Pechnik, A. (1885). Zarys psychologii dla użytku szkót średnich. Lwów: Nakładem Towarzystwa Pedagogicznego.

Potocki, J.K. (1897a). O terminologii psychologicznej. Przeglad Filozoficzny, 1(1), 31-52.

Potocki, J.K. (1897b). Terminologia psychologiczna. Przegląd Filozoficzny, 1(2), 19-24.

Radziwiłłowicz, R. (1911). Słownik psychologii, neurologii, psychopatologii i nauk pokrewnych. Ruch Filozoficzny, 2, 17-18.

Radziwiłłowicz, R. (1926). Podstawy psychologji w zarysie. Warszawa: Druk. i Lit. Jan Cotty.

Richet, C. (1887/1890). Zarys psychologii ogólnej. Transl. A. Leska. Kraków: Gebethner i S-ka.

Rzepa, T., Dobroczyński, B. (2019). Historia polskiej myśli psychologicznej. Wydanie nowe. Warszawa: Wydawnictwo Naukowe PWN.

Struve, H. (1863). Logika poprzedzona wyktadem psychologii. Warszawa: (no publisher).

Witwicki, W. (1926-1927). Psychologia. Dla użytku słuchaczów wyższych zakładów naukowych, t. 1-2. Lwów: Wydawnictwo Zakładu Narodowego im. Ossolińskich.

Witwicki, W. (1928). Zarys psychologji. Podręcznik dla uczniów szkót średnich i seminariów nauczycielskich. Lwów-Warszawa: Książnica Atlas.

Wundt, W. (1864/1874). Wykłady o duszy ludzkiej i zwierzęcej. Kraków: Nakładem A. Dygasińskiego i Małuji.

Zagórzański, J (1869). Psychologia empiryczna dla wyższych gimnazyów podtug dra Roberta Zimmermana. Rzeszów: Druk i nakład Księgarni J.A. Pelara.

Ziemba, T.Z. (1877). Psychologia. Kraków: Nakładem autora.

\section{STRESZCZENIE}

Podręczniki są jednym z ważniejszych źródeł wiedzy na temat zagadnień tworzących obszar badań danej dyscypliny naukowej. Zawarta w nich wiedza odnosi się do aktualnego stanu poznania, odzwierciedla terminologię naukową, sposób definiowania różnych zjawisk oraz sposób rozumienia ich mechanizmów i nadawania im znaczenia w systemie danej nauki. Rola podręczników 
w kształceniu szkolnym i uniwersyteckim jest więc podstawowa. Poniekąd inspirują one także kierunki i tematy badań. W artykule naszkicowano miejsce emocji i uczuć w najważniejszych podręcznikach psychologii wydanych w języku polskim w latach 1863-1914. To zarówno dzieła psychologów polskich, jak i prace tłumaczone z języków obcych. Podręczniki te powstały w okresie, w którym jeszcze nie było ustalone polskie naukowe słownictwo psychologiczne. W opracowaniu opisano sposób prezentowania wiedzy o uczuciach i emocjach oraz ich klasyfikowania, a także podstawowe poglądy na temat ich genezy i związków z innymi zjawiskami świadomości. Był to stan wiedzy, który można uznać za punkt wyjścia do dalszego rozwoju psychologii emocji w Polsce.

Słowa kluczowe: emocje; uczucia; podręczniki psychologii; historia psychologii w Polsce 